\title{
First record of Phytophthora cinnamomi on cork and holm oaks in France and evidence of pathogenicity
}

\author{
Cécile Robin ${ }^{a *}$, Marie-Laure Desprez-Loustau ${ }^{\mathrm{a}}$, Gilles Capron ${ }^{\mathrm{a}}$, \\ Claude Delatour ${ }^{\mathrm{b}}$
}

a Laboratoire de pathologie forestière, station de pathologie végétale, Inra Bordeaux,
BP 81,33883 Villenave d'Ornon, France
b Laboratoire de pathologie forestière, Inra Nancy, 54280 Champenoux, France

(Received 25 August 1997; accepted 20 February 1998)

\begin{abstract}
In 1995 and 1996, a survey for the presence of Phytophthora cinnamomi in cork and holm oak sites in southeastern France was carried out. Twenty-four sites were chosen. Tree decline severity and other characteristics were assessed. Subplots of four trees were more fully investigated: relative soil water content was assessed and Phytophthora isolation was attempted from soil samples. When cortical lesions were observed, isolations were carried out from infected tissues. In six cork oak and one holm oak sites, $P$. cinnamomi was isolated from soil or trunks. All the different isolates obtained in 1995 were aggressive on cork and holm oaks. However, these species were less susceptible than Castanea sativa and more susceptible than $Q$. rubra. These results confirm the pathogenicity of $P$. cinnamomi towards Mediterranean oaks and its possible involvement in the decline process of these species. (@) Inra/Elsevier, Paris.)
\end{abstract}

Quercus suber / Quercus ilex / Phytophthora cinnamomi / soil detection / trunk cankers / cork

Résumé - Première mention de Phytophthora cinnamomi sur chêne liège et chêne vert en France et mise en évidence de son pouvoir pathogène. Phytophthora cinnamomi a été recherché dans des sites de chênes liège et verts en 1995 et 1996. Vingt quatre sites ont été choisis, dans lesquels l'intensité du dépérissement et les principales caractéristiques stationnelles ont été décrites. Au pied de quatre arbres par site des échantillons de sol ont été prélevés pour mesurer la teneur relative en eau du sol et y rechercher $P$ cinnamomi. Des isolements ont été tentés à partir des tissus prélevés dans des chancres corticaux. $P$ cinnamomi a été isolé dans six sites de chêne liège et un de chêne vert. Les différents isolats obtenus en 1995 étaient pathogènes sur chênes vert et liège. Cependant, ces deux espèces présentent une sensibilité intermédiaire entre celles de Castanea sativa et de $Q$. rubra. Ces résultats confirment le pouvoir pathogène de $P$. cinnamomi sur ces chênes méditerranéens et sa possible implication dans le processus de dépérissement de ces essences. (C) Inra/Elsevier, Paris.)

Quercus suber / Quercus ilex / Phytophthora cinnamomi / détection dans le sol / chancres corticaux / liège

* Correspondence and reprints

E-mail: robin@bordeaux.inra.fr 


\section{INTRODUCTION}

Cork oak (Quercus suber L.) is a native species in southwestern and southeastern France. The main cork production areas are located in Pyrénées Orientales, in Var and in Corsica. In Pyrénées Orientales most of the stands are poorly managed plantations invaded by other species and are at the limit of the natural range of $Q$. suber, which is determined by winter temperature, annual rainfall (from 400 to $2500 \mathrm{~mm}$, but always with dry summers) and soil (not calcareous) [23]. In Var, most of the cork oaks originate from natural regeneration. In both cases, the cork oak forest is old and damaged, and has suffered several forest fires. Only 4785 out of 15625 ha are managed in Pyrénées Orientales, and 23000 out of 33030 ha in Var. In 1990, 700 and $450 t$ of cork were harvested, respectively, in Pyrénées Orientales and Var. The objective is to increase the production to 800 and $2900 \mathrm{t}$ (data from the Inventaire Forestier National). Toward this aim, management of old sites and afforestation with cork oak have been increasing since 1980 . The natural range of holm oak (Q. ilex L.) includes the entire Mediterranean area, primarily on calcareous soils. Offering a protection against soil erosion and forest fires, the pure or mixed coppices of holm oak are an important feature of the Mediterranean ecosystem.

Since 1989, a decline in cork and holm oaks has been reported in southeastern France $[2,11]$. Oak decline is a complex disease, more properly a general syndrome, whose importance has increased in the last 20 years $[6,17]$. In the Mediterranean area, a decline in cork, holm and turkey oak ( $Q$. cerris $\mathrm{L}$.) has been reported by several authors $[4,16]$. The symptoms of decline include crown transparency, chlorosis, microphylly and abnormal fructing. The decline may be slow and characterised by a gradual crown defoliation, resulting in several dead branches, or quick and characterised by a sudden death, with leaves turning yellow before drying on the tree $[4$, 5]. In 1993, Brasier et al. reported the presence of Phytophthora cinnamomi Rands in a number of lberian oak sites and suggested that this pathogen could be involved in the oak decline. Ever since, other Phytophthora species have been isolated from declining oaks ( $Q$. robur L. and Q. petrea (Matt) Lieb) in central Europe [10].

$P$. cinnamomi is a soil-borne pathogen, belonging to the Oomycetes group. It has caused important losses and damage in several parts of the world on several host plants [26]. $P$. cinnamomi primarily infects the unsuberised roots, responsible for water absorption, and extends to larger roots, collar and trunks, causing cortical cankers. Secondary symptoms are similar to those caused by drought: infected plants turn chlorotic, dieback and collapse [25]. Death often occurs several years after infection. In field resistant species root infection and cankers are the principal damage to the host. However, rapid deaths of trees may occur when environmental conditions favour an extensive root destruction, due to an increasing inoculum build-up in the soil, and symptom expression [21]. Brasier et al. [4] suggested that in $Q$. suber and $Q$. ilex, loss of fine roots due to $P$. cinnamomi would interact with drought and other factors such as site disturbance, leading either to rapid wilting or gradual defoliation and dieback. In France, this pathogen is responsible for important losses in woody plant nurseries [24] and causes the ink disease of chestnut (Castanea sativa Mill) and of red oak (Q. rubra L.). The ink disease of chestnut was introduced, from Spain to the southwestern area of France, in the Basque country, in the year 1860 , and quickly spread in the southeastern part of the country causing the decline of many chestnut groves [9]. This disease was reported in the departments of Hérault and Corsica as early as 1925 . The major feature of ink disease on red oak is the occurrence of collar and stem stripe cankers, infected trees do not show any sign of decline $[15,19]$. Controlled inoculations confirmed that red 
oak is more resistant to $P$. cinnamomi root infection as compared to chestnut which is highly susceptible [13]. Ink disease of red oak was also reported for the first time in the Basque country, but it did not spread further than the southwestern bank of the Garonne river [12].

The aim of this study was to investigate the possible association of $P$. cinnamomi with the oak decline observed in French Mediterranean oak sites. The first point was the search for the presence of the pathogen in declining cork and holm oak stands. Experiments were then carried out to assess the pathogenicity of $P$. cinnamomi isolates on seedlings of cork and holm oaks.

\section{MATERIALS AND METHODS}

\subsection{Study sites and sampling surveys}

We selected 16 cork oak stands: ten in Var (sites 1-6 in the Maures mountains and 7-10 in Esterel), six in Pyrénées Orientales (sites 11-16) and eight holm oak stands in Vaucluse (sites 17-20) and in Bouches-du-Rhône (sites 21-24, cf. table I and figure I). Decline was observed at different levels in all these stands. Annual rainfall was obtained from weather stations of the Metéorologie Nationale in Perpignan (Pyrénées Orientales) and Le Luc (Var, figures $I$ and 2). Annual water status has been in deficit in southeastern France since 1988. In Var, the drought lasted 4 years, the annual deficit reached $532 \mathrm{~mm}$ in 1989. During this period, monthly rainfalls were below normal in winter as well as in summer. Again in 1995, a deficit of $180 \mathrm{~mm}$ was observed. In Pyrénées Orientales, the drought was less severe than in Var in the years 1988 to 1991, and 1992 was rainy, but another episode of drought occurred in 1994 and 1995.

Two sampling surveys were performed in June and November 1995 in Var, and one in June 1996 in the other sites. In each stand, a subplot of four trees (A-D), distant from each other, was established. In each subplot, crown defoliation level was assessed and under each tree, four soil samples were taken, after litter removal, from the 20 top centimetres, and bulked in order to have one sample by tree (between 750 and $\left.1000 \mathrm{~cm}^{3}\right)$. In June 1995 and 1996 , relative soil water content (RSWC) of each soil sample was determined according to the formula:

RSWC $=(F W-D W) / D W$ where FW was the fresh weight of the sample and DW the dry weight. In Var, the same subplots were studied in June and in November 1995.

Additional observations were made in certain sites. A few roots were hand-excavated in two trees (site 10) and in several seedlings (site 6). Samples from fine and larger ( $1 \mathrm{~cm}$ in diameter) necrotic roots were brought back to the laboratory for further observation and isolation. In and outside the subplots (trees labelled E-H), trees exhibiting bleeding cankers at the collar or on the trunk were thoroughly examined, the cortical tissues removed and, when necessary, sampled.

\subsection{Isolation methods}

Soil isolation of Phytophthora fungi was attempted from soil suspensions (10 g per sample suspended in $20 \mathrm{~mL}$ of tap water). The selective medium (PARBHy) contained $15 \mathrm{~g} \cdot \mathrm{L}^{-1}$ of malt extract, $20 \mathrm{~g} \cdot \mathrm{L}^{-1}$ of agar, $10 \mathrm{mg} \cdot \mathrm{L}^{-1}$ of pimaricin, $250 \mathrm{mg} \cdot \mathrm{L}^{-1}$ of salt ampicillin, $10 \mathrm{mg} \cdot \mathrm{L}^{-1}$ of rifampicin, $15 \mathrm{mg} \cdot \mathrm{L}^{-1}$ of benomyl and $50 \mathrm{mg} \cdot \mathrm{L}^{-1}$ of hymexazol [19].

Four isolation methods were used in this study:

1) direct plating of soil suspensions (June and November 1995): after a 3-day incubation, $5 \mathrm{~mL}$ of soil suspension were put on one PARBHy plate per sample and washed with water after $24 \mathrm{~h}$ (at $25^{\circ} \mathrm{C}$, in the dark);

2) baiting with chestnut shoots (June and November 1995, June 1996): shoots (5 $\mathrm{mm}$ in diameter) of chestnut seedlings were cut to $7 \mathrm{~cm}$ long (two leaves), dipped in soil suspension (one segment was standing upright in each suspension) and after a 9-day incubation (at $20-25^{\circ} \mathrm{C}$, on laboratory bench) they were plated onto PARBHy;

3) baiting with $1-\mathrm{cm}$ diameter discs from red oak leaflets (June 1996): discs of leaves (not fully expanded) of $Q$. rubra were floated on each soil suspension (ten discs per sample) and plated onto PARBHy after I day of incubation;

4) isolation from bark tissues (November 1995 and June 1996): small pieces were surface sterilised $\left(30 \mathrm{~s}\right.$ in alcohol $\left.70^{\circ}\right)$, rinsed in sterile water and put onto PARBHy. 


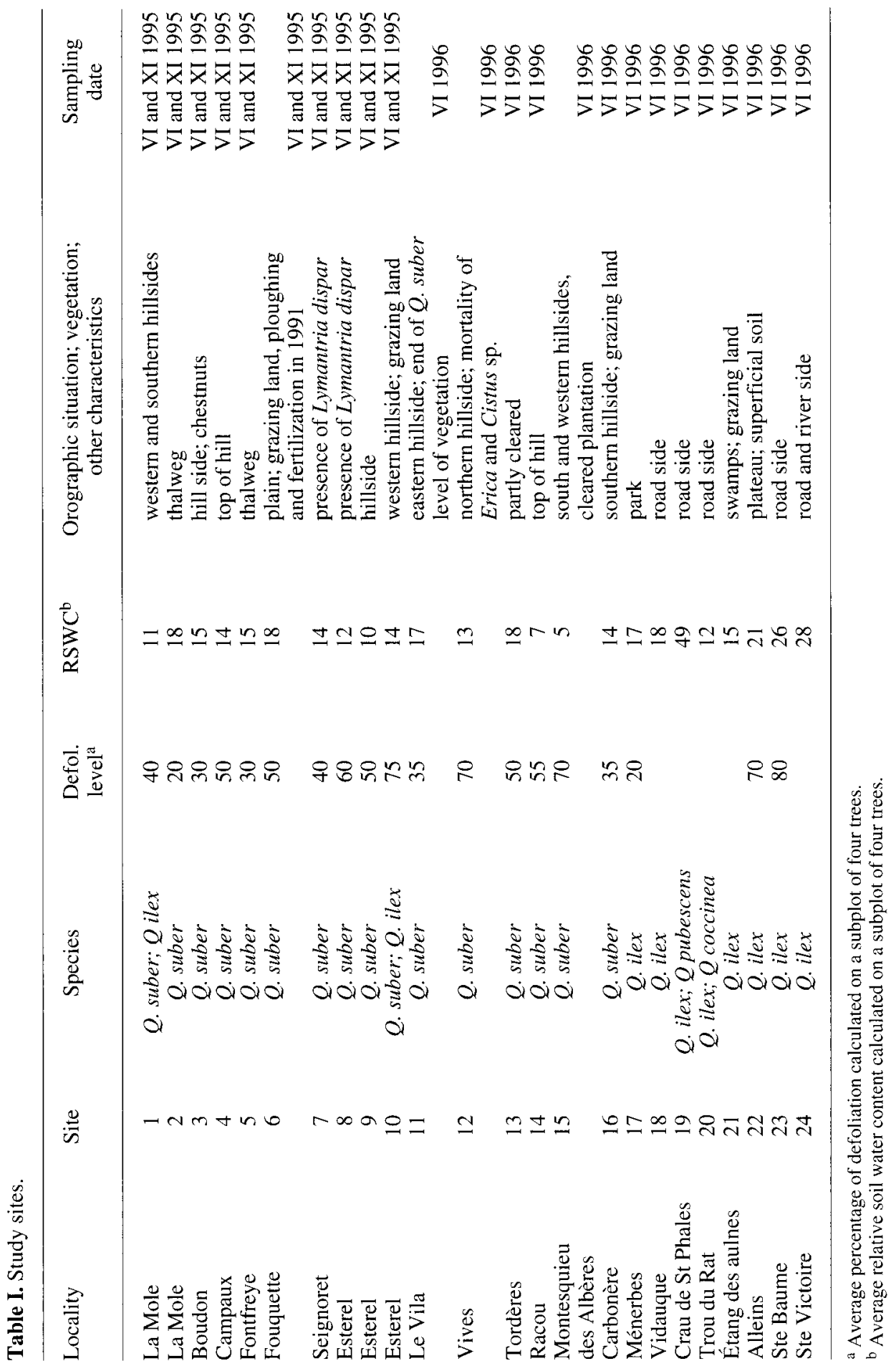




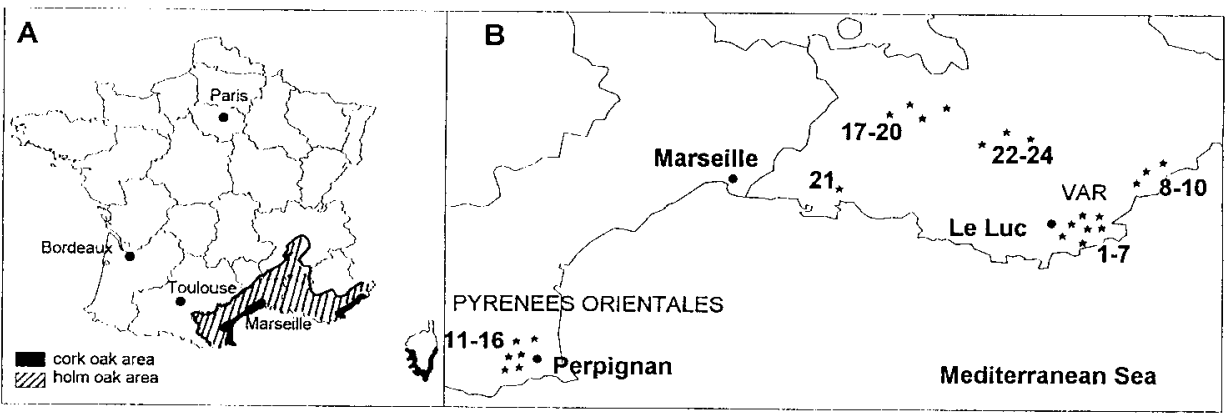

Figure 1. A) Extension areas of cork and holm oak in southeastern France. B) Localisation of the studied cork and holm oak sites.

A- Le Luc

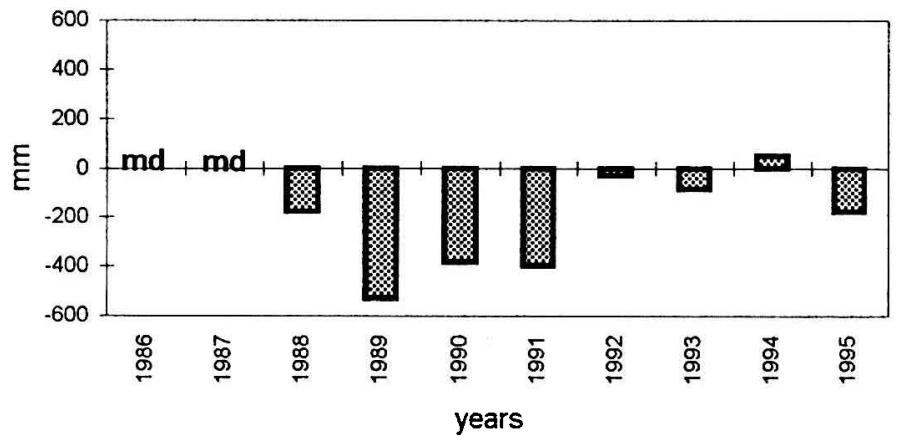

B- Perpignan

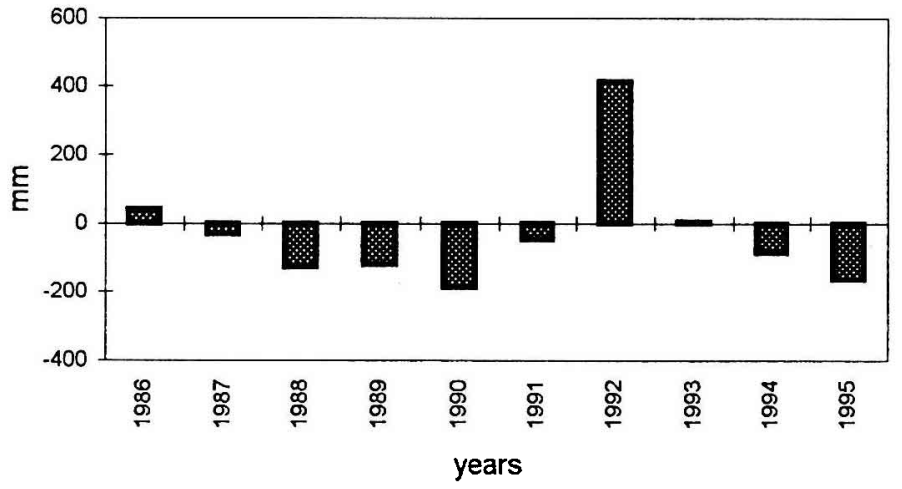

Figure 2. Annual water status (annual - normal rainfalls; normals are calculated over 20 years) in Var (A: Le Luc) and in Pyrénées Orientales (B: Perpignan). md: missing data. 
Soil, baits and necrosed tissues were incubated for 2 days at $25^{\circ} \mathrm{C}$, in the dark, before being assessed for the presence of Phytophthora sp. isolates in the samples.

\subsection{Identification}

Phytophthora isolates, identified according to their mycelial morphology [18], were subcultured on different media in order to obtain pure cultures and sporulation. For the production of sporangia, discs were cut from potato dextrose agar cultures and immersed in a soil filtrate, as described by Ribeiro [18]. Microscopic examinations were made after $2-3$ days. For the production of oospores, isolates were grown on a carrot medium $\left(50 \mathrm{~mL} \cdot \mathrm{L}^{-1}\right.$ of carrot juice, $18 \mathrm{~g} \cdot \mathrm{L}^{-1}$ of agar, $400 \mathrm{mg} \cdot \mathrm{L}^{-1} \mathrm{Ca}\left(\mathrm{NO}_{3}\right)_{2}$, $1.15 \mathrm{~g} \cdot \mathrm{L}^{-1}$ of $\mathrm{MgSO}_{4}, 150 \mathrm{mg} \cdot \mathrm{L}^{-1}$ of $\mathrm{KH}_{2} \mathrm{PO}_{4}$ and $60 \mathrm{mg} \cdot \mathrm{L}^{-1}$ of $\mathrm{KCl}$ ), for 4 days in the dark at $20^{\circ} \mathrm{C}$. Known $P$. cinnamomi isolates of mating type $\mathrm{A} 1$ and $\mathrm{A} 2$ were paired with each of the isolates.

\subsection{Taproot inoculations}

Inoculations with $P$. cinnamomi isolates obtained in 1995 (table II) were carried out on $Q$. suber and $Q$. ilex seedlings following the method of Desprez-Loustau and Dupuis [7]. Standard isolates from our collection were included for comparison as references (isolates 9 and 305

Table II. Phytophthora cinnamomi recovery from soil collected under oaks and from plants in declining oak stands.

\begin{tabular}{|c|c|c|c|c|c|c|}
\hline Site-tree & Isolate & $\begin{array}{c}\text { Soil/plant } \\
\text { organ }\end{array}$ & $\begin{array}{l}\text { Defol. } \\
\text { level }^{\text {a }}\end{array}$ & RSWC $^{b}$ & $\begin{array}{l}\text { Isolation } \\
\text { method }^{\mathrm{c}}\end{array}$ & $\begin{array}{l}\text { Month of } \\
\text { isolation }\end{array}$ \\
\hline $2-E$ & 567 & Q. suber trunk & & & 4 & XI 1995 \\
\hline $2-\mathrm{F}$ & 566 & Q. suber trunk & & & 4 & XI 1995 \\
\hline $3-\mathrm{E}$ & 565 & Q. suber trunk & & & 4 & XI 1995 \\
\hline $6-A$ & 547 & soil & 20 & 11 & 1,2 & V1 1995 \\
\hline 6-C & 548 & soil & 35 & 13 & 2 & VI and XI 1995 \\
\hline $6-\mathrm{E}$ & 560 & Q. suber trunk & 55 & & 4 & XI 1995 \\
\hline $6-\mathrm{F}$ & 561 & Q. suber trunk & & & 4 & XI 1995 \\
\hline 6-G & 562 & Q. suber trunk & & & 4 & XI 1995 \\
\hline $6-\mathrm{H}$ & 563 & Q. suber trunk & & & 4 & XI 1995 \\
\hline 6 & 564 & Q. suber seedling & & & 4 & XI 1995 \\
\hline $10-\mathrm{A}$ & 549 & soil & 60 & 11 & 1 & VI 1995 \\
\hline $10-A$ & 568 & soil & & & 2 & XI 1995 \\
\hline $10-\mathrm{A}$ & 557 & Q. suber root & & & 4 & XI 1995 \\
\hline $10-B$ & 550 & soil & 60 & 14 & 2 & VI and XI 199 \\
\hline $10-\mathrm{B}$ & 552 & Q. suber trunk & & $x$ & 4 & XI 1995 \\
\hline $10-\mathrm{D}$ & 551 & soil & 50 & 19 & 2 & VI 1995 \\
\hline $10-\mathrm{E}$ & 553 & Q. suber trunk & & & 4 & XI 1995 \\
\hline $10-F$ & 554 & Q. suber trunk & & & 4 & XI 1995 \\
\hline $10-\mathrm{G}$ & 555 & Q. suber trunk & & & 4 & XI 1995 \\
\hline $10-\mathrm{G}$ & 556 & Q. suber trunk & & & 4 & XI 1995 \\
\hline 10 & 559 & Erica sp. root & & & 4 & XI 1995 \\
\hline $12-B$ & & soil & 80 & 8 & 3 & VI 1996 \\
\hline $15-\mathrm{B}$ & & soil & 80 & 6 & 2 & VI 1996 \\
\hline $15-\mathrm{C}$ & & soil & 30 & 6 & 3 & VI 1996 \\
\hline $15-\mathrm{D}$ & & soil & & 3 & 2,3 & VI 1996 \\
\hline $21-E$ & & soil & & 30 & 2,3 & VI 1996 \\
\hline 21-E & & Q. ilex trunk & & $x$ & 4 & VI 1996 \\
\hline $21-\mathrm{F}$ & & $\mathcal{Q}$. ilex trunk & & & 4 & VI 1996 \\
\hline
\end{tabular}


from $Q$. rubra, isolate 57 from $Q$. robur and 64 from $C$. sativa). Scedlings (provenance Var, France) were grown from acorns in 'mini-rhi7otrons' at $25^{\circ} \mathrm{C}$ with a $16-8-\mathrm{h}$ day/night period. When taproot length reached $10 \mathrm{~cm}$, inoculation was performed by putting a disc $(5 \mathrm{~mm}$ in diametcr) taken from a $P$. cinnamomi culture on the taproot tip (three seedlings per isolate). Lesion length was visually assessed and measured 10 days after inoculation.

\subsection{Inoculation by infested soil}

The study was performed on cork oak (Maures, southeast France) and holm oak (Spanish origin) seedlings in their first growing season. Red oak (southwest France) and chestnut (southwest France) seedlings were used as reference species. Six-month-old seedlings were obtained from a commercial nursery, in pressed peat moss.

Millet seeds were sterilised in erlenmeyer llasks by two autoclavings at a 24-h interval. They were then inoculated by adding ten dises ( $5 \mathrm{~mm}$ in diameter) cut out of $P$. cinnamomi cultures (isolate 9) to each flask. Incubation took place in the dark at $25^{\circ} \mathrm{C}$ for 1 month. The potting medium (two thirds peat, one third sand) was contaminated with infected millet seeds, at a rate of $0.5 \%$ ( $\mathrm{vol} / \mathrm{vol}$ ). Plant inoculation was achieved by transplanting seedlings into this infested medium, which was immediately watered. No millet seeds were added for the control plants. Twenty-five plants were inoculated for each species, with an equal number of control plants. After inoculation, seedlings were placed in a growth chamber (16-8-h photoperiod, $\left.23.5 / 21^{\circ} \mathrm{C}, 75 \% \mathrm{RH}\right)$ and watered every 2 days. From the second week till the end of the experiment, predawn leaf water potential (PWP) measurements were made weekly using a Scholander pressure chamber. Seven weeks after inoculation, an estimation of root system development was made using a five-grade scoring (from 0 : no intact secondary roots to 4 : healthy root system). The mean score for each treatment was then calculated. The percentage of root loss was obtained by relating each score to the mean score of uninfected control plants of the same species. Phytophthora isolations on PARBHy were carried out from the taproot. After 3 days incubation, the length of infected taproot (i.e. where an outgrowth of $P$. cinnamomi could be seen) was measured, as well as the total taproot length. This allowed an estimate of the percentage of infected taproot (PIT).

\section{RESULTS}

\subsection{Recovery of Phytophthora sp. isolates}

In Var, in June 1995, Phytophthora sp. were detected in soil from two cork oak subplots (sites 6 and 10). Detection was positive in one soil sample by direct plating (tree 6A) and in five samples by chestnut baiting (6-A, 6-C, 10-A, 10-B, 10-D, cf. table II). RSWC of these soil samples varied from 11 to $14 \%$ and crown defoliation of the related oaks varied from 20 to $60 \%$. In November 1995, Phytophthora sp. were isolated, by chestnut baiting, from soil removed from under the trees 6-C, 10-A and 10-B. In Pyrénées Orientales, in June 1996, Phytophthora sp. isolates were obtained from two cork oak sites (12 and 15, table II). Chestnut baiting allowed the recovery in two soil samples (15-B and 15-D), and oak leaf baiting in three of them (12-B, 15-C and 15-D). The RSWC of these soil samples was less than $10 \%$ (table II).

Phytophthora sp. was also isolated from root lesions of one mature cork oak (site 10 ), from the taproot of two cork oak seedlings (site 6) and from roots of declining Erica sp. plants (site 10).

In sites 2, 3,6 and 10, several cork oaks, not severely declining but exhibiting typical bleeding cankers (figure $3 A, B$ ) were found outside the subplots and in one case at the edge of the site (tree $3-E$ ). Cankers were located at the base of the trees. They differed in surface appearance according to the date of the last cork removal and therefore to the thickness of cork. When cork was old, a few bark fissures from which exudates were oozing, made it possible to detect the canker. When the cork was smooth, after recent cork removal, black spots were more conspicuous. Under the cork, phloem and cambial necrosis, which turned dark brown, was delimited by a black line. Isolations from tissues samples were attempted only 3-5 days after sample removal. At this date 
it was not easy to distinguish necrosed from healthy tissues because of tannins. However, Phytopthora sp. were recovered with a high frequency from canker samples (11 positive isolations from the 12 trees sampled, cf. table II). For each canker, recovery percentage varied from 4 (one colony of Phytophthora sp. obtained from 23 canker pieces plated) to 46 ( 7 colonies from 15 bark pieces). No typical Phytophthora cankers were found at the oak sites of the Pyrénées Orientales.

We were not able to detect Phytophthora sp. in soil from holm oak sites, except at site 21. Here, two trees ( $E$ and $F$ ) exhibited basal cankers, spreading up to $1 \mathrm{~m}$ high (figure $3 C, D)$. They were located in a very swampy part of the site, and were yellowing.
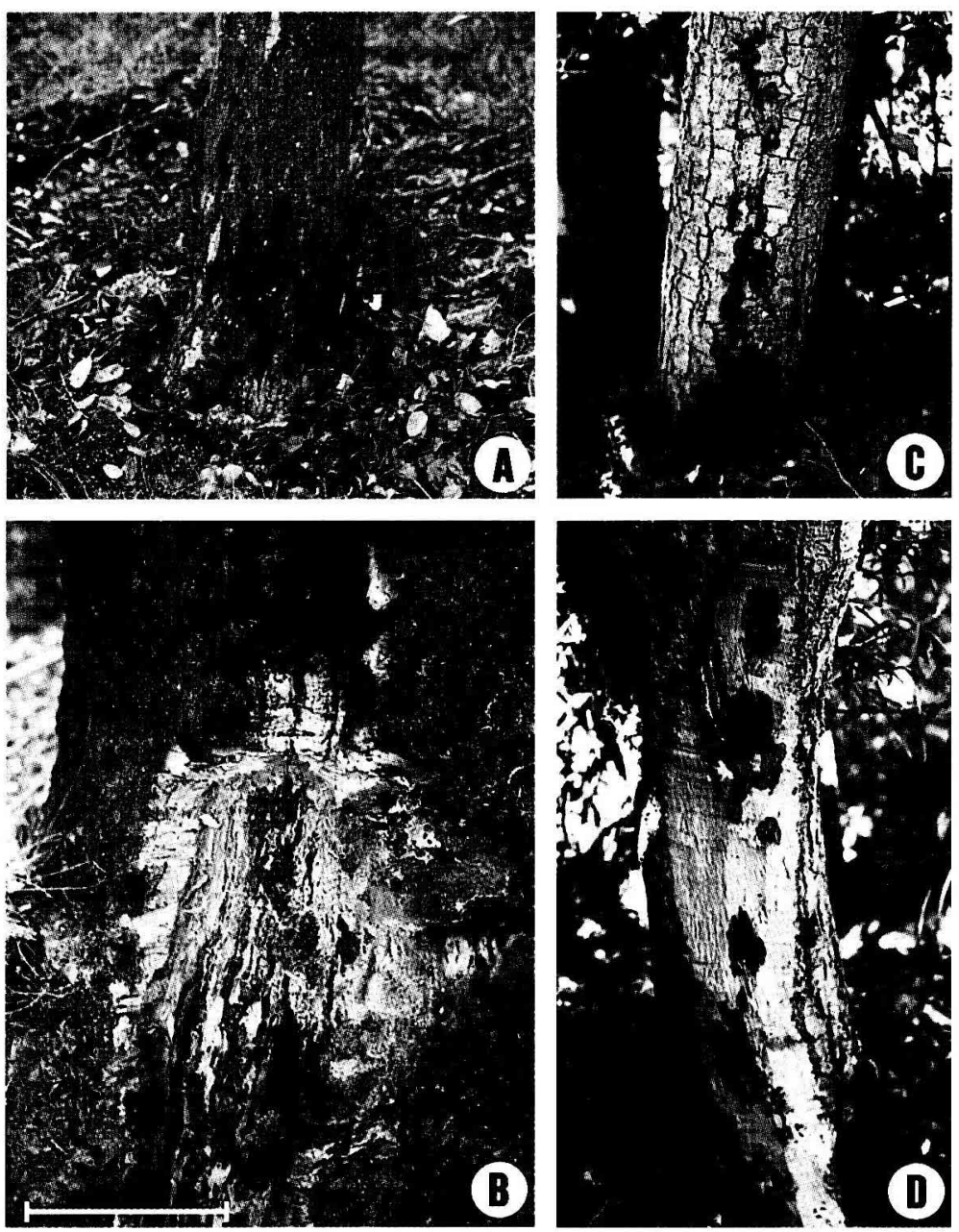

Figure 3. A) Bleeding canker at the base of a cork oak tree (30-cm-trunk diameter) caused by Phytophthora cinnamomi. B) Internal lesion of cortical tissues caused by $P$. cinnamomi in cork oak tree (bar $=15 \mathrm{~cm}$ ). C) Bleeding canker at the base of a holm oak tree $(15-\mathrm{cm}$-trunk diameter) caused by $P$. cinnamomi. D) Internal lesion of cortical tissues in the same tree. 
Typical phloem and cambium necrosis was observed, from which Phytophthora sp. was isolated. A soil sample, removed from under tree E, provided Phytophthora (with both chestnut and oak leaf baiting). Several other bark disorders, with black exudations were observed on holm oaks. But the associated necroses were not similar to the ones caused by $P$. cinnamomi in oaks and the pathogen was never recovered.

All the isolates recognised as Phytophthora sp. were identified as $P$. cinnamomi according to the different criteria used in this study. Typical mycelium, sporangia and oospores were observed. All the isolates obtained in this study formed oospores only in presence of the A1 mating type isolate and therefore were of the opposite type.

\subsection{Site characteristics}

In Var, only one tree in all the subplots we examined displayed symptoms of quick decline (site 6, tree B). Other trees showed symptoms of slow decline, with defoliation intensity ranging from 15 to $80 \%$. In Pyrénées Orientales, cork oaks were resprouting after a severe defoliation caused by the drought of 1995. For holm oaks, it was sometimes difficult to provide a score on an individual tree basis, because they were mainly coppice stems and more shrubs than trees. Sampled trees were taken from groups showing light to severe decline, sometimes with dead stems or yellowing crowns.

Sites where $P$. cinnamomi was isolated from soil had an average defoliation level of $50 \%$ or more (table I). However, cork oaks under which the pathogen was detected were not more affected by defoliation than the others (in Var, $F_{(34.4)}=0.90$, in Pyrénées Orientales $\left.F_{(19,2)}=1.07\right)$. Average defoliation score at the sites 6 and 10 was $50 \%$, and the percentage of crown defoliation of the trees under which $P$. cinnamomi was detected was comprised between 20 and 60 . Decline at the sites 12 and 15 was more severe (average defoliation score was $68 \%$ ) and affected Cistus and Erica sp. At site 15, decline patches were obvious.

On the basis of the RSWC there were no significant differences among the subplots studied in Var in 1995 (F $=0.61,9 \mathrm{df}, P=$ 0.78 , the general mean value of RSWC was $14 \%$ ). Differences between subplots studied in 1996 were significant on RSWC ( $F=$ $7.69,13 \mathrm{df}, P=0.0001$ ). The subplot mean values varied from $4.5 \%$ (site 15 ) to $49 \%$ (site 19), the general mean value being $18 \%$. $P$. cinnamomi was isolated in soil samples with RSWC as low as $6 \%$ (site 15) and as high as $30 \%$ (site 21 , table $I I$ ). It was detected in four moist sites (sites 6 and 21 : isolation from soil, sites 2 and 3: isolation from trunks) and in three dry ones (10, 12 and 15). There was no relationship between high RSWC and presence of $P$. cinnamomi at the site.

\subsection{Pathogenicity of $P$. cinnamomi isolates to cork and holm oaks}

Ten days after inoculation, all the 22 studied isolates induced lesions on the taproot of both cork and holm oak seedlings (figure 4) but no mortality. Significant differences in lesion length were noted between isolates, and between species but the isolate-species interaction was not significant. Sixteen isolates caused longer lesions on $Q$. ilex than on Q. suber, three isolates similar lesions and the last four smaller lesions (figure 4). The studied isolates were mostly equally or more virulent than the two weakly pathogenic isolates (57 and 64) used as references. Six and 12 isolates were more aggressive than the standard isolate 9 on holm and cork oak, respectively.

\subsection{Cork and holm oak susceptibility to $P$. cinnamomi}

Data on taproot infection, root loss and mortality rate are presented in figure 5. The 


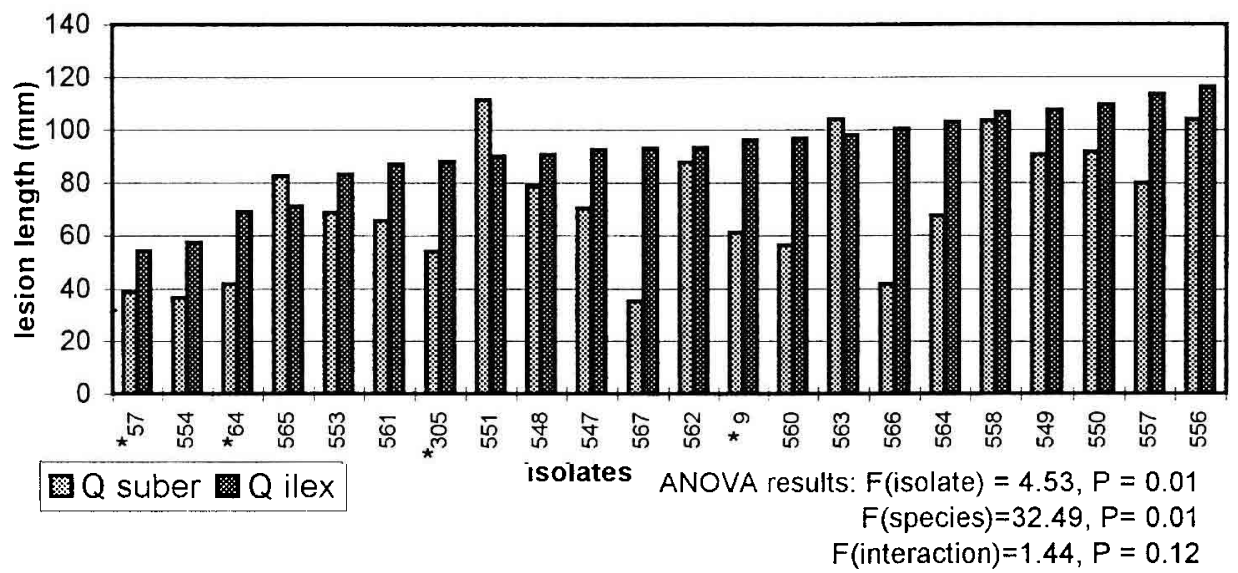

Figure 4. Lesion lengths caused by Phytophthora cinnamomi isolates obtained from cork oak sites on Quercus suber and $Q$. ilex seedlings. Mean values of three replicates. Results of the analysis of variance performed on lesion length. * Reference isolates.

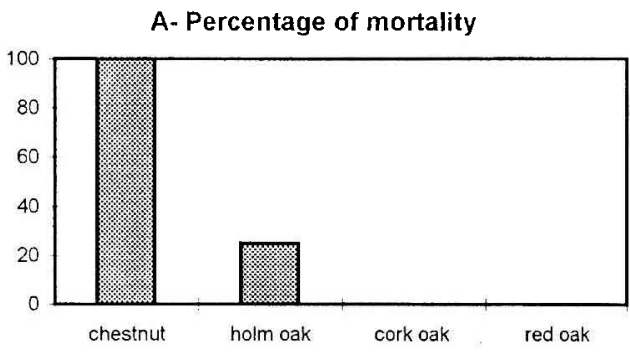

B- Percentage of taproot infection.

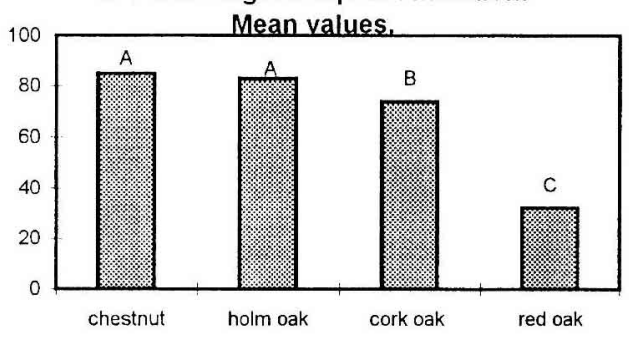

Figure 5. Effect of inoculation with $P h y$ tophthora cinnamomi on chestnut and oak seedlings. Means with the same letter are not significantly different according to Student-Newman-Keul's test.

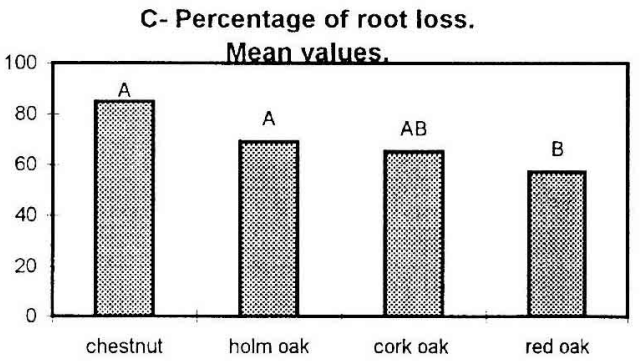



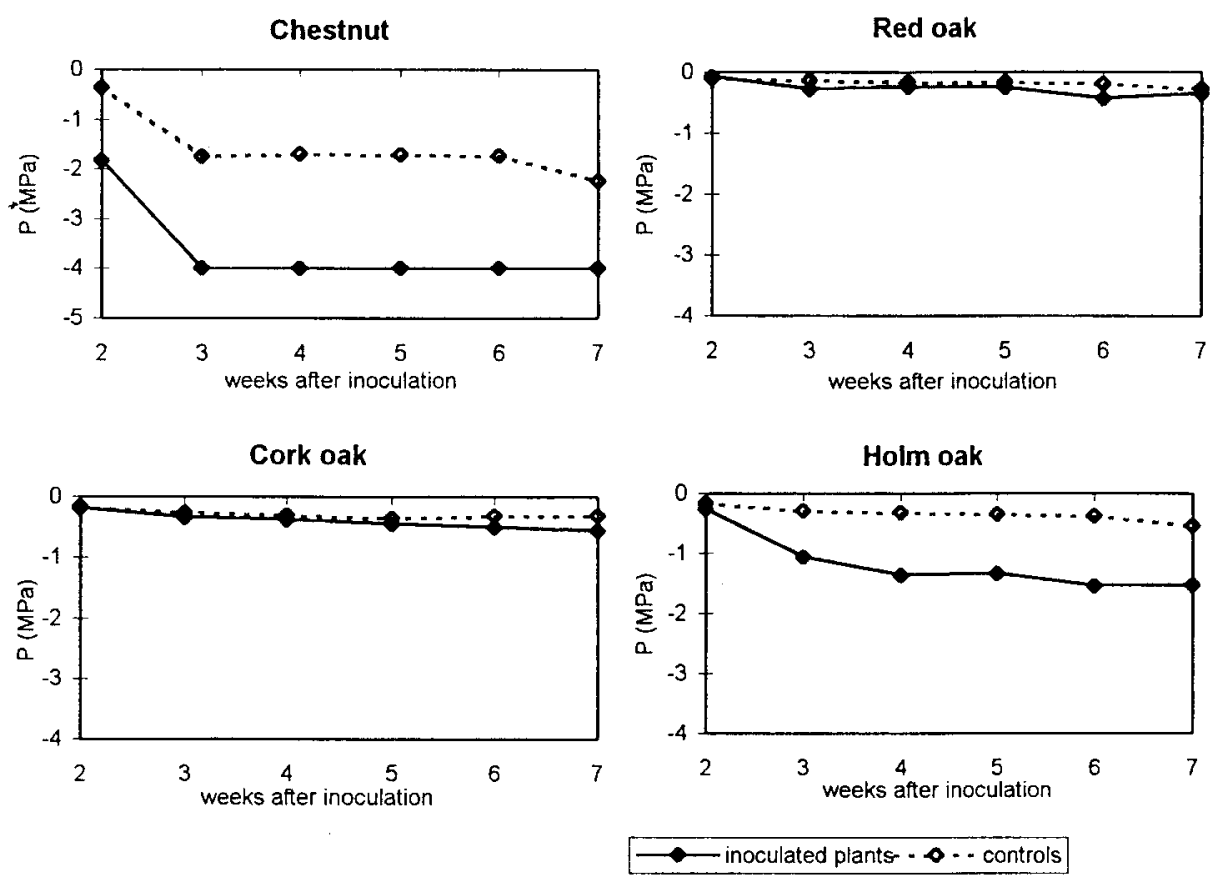

Figure 6. Evolution of predawn water potential in chestnut and oak seedlings after inoculation with Phytophthora cinnamomi.

evolution of the predawn leaf water potential during 7 weeks after inoculation is given in figure 6.

Chestnut seedlings exhibited a high susceptibility to $P$. cinnamomi, with a mortality and taproot infection rate of $100 \%$, a mean PIT and a root loss of $85 \%$ in inoculated plants. In all inoculated plants the leaf water potential reached $-4 \mathrm{MPa}$ in 3 weeks. In control plants, a decrease in PWP was measured. Reisolation attempted in control plants showed that four plants had accidentally been contaminated

In contrast, there was no mortality of red oak seedlings. Although seven seedlings out of eight had an infected taproot, with a mean PIT of $22 \%$, root loss (57\%) was significantly less than that of chestnut. The PWP of inoculated seedlings was unaffected by infection as shown by the very slight decrease in water potential.

Cork oak expressed a quite similar behaviour to red oak in this experiment: there was no mortality and PWP followed the same course in inoculated and in control plants. However, plants were more severely infected than red oaks: all the plants were taproot infected, the mean PIT was 0.73 and the root loss $64.8 \%$. Holm oak, with $25 \%$ mortality after inoculation, appeared more susceptible than cork oak, for which no mortality was observed. Root loss and PIT were not different from chestnut. Although no systematic isolations were attempted from fine and secondary roots, it seemed that taproot infection resulted from these root infections since fine roots were missing or black in infected plants and 
necrosis in the taproot was most often localised at the insertion of secondary roots.

\section{DISCUSSION}

This study is the first report of $P$. cinnamomi being isolated from cork and holm oak in France. All the Phytophthora sp. isolates we obtained in isolation plates proved to be $P$. cinnamomi of the A2 mating type. Isolation of $P$. cinnamomi from cortical cankers in cork oaks is in agreement with reports of Mircetich et al. [14] and of GlobaMikhajlenko [8], who described, in California and in Russia, respectively, such cankers caused by this pathogen on $Q$. suber. Cankers were very similar to the ones observed on $Q$. rubra and $Q$. robur [15]. All the cankers we suspected to be caused by $P$. cinnamomi yielded this pathogen, showing that lesions caused by $P$. cinnamomi were quite characteristic and that our isolation method was effective. Such cankers can impede the cork removal, since the structure and integrity of cortical tissues are affected, and thus can cause important loss in cork production. We also isolated $P$. cinnamomi from cortical cankers of two holm oak trees at site 21. As far as we know this is the first time that this symptom has been described in holm oak.

Our results are also in agreement with the first report of this pathogen, by Brasier et al. [4] in declining Mediterranean oak sites in Spain and Portugal. These authors isolated $P$. cinnamomi from soil and roots, but did not mention the occurrence of cortical cankers in declining oaks. However, in $1995 P$. cinnamomi was isolated from typical cankers (J. Aguirre, C. Delatour and C. Robin, unpublished result), in two cork oaks in the Parque Natural de los Alcornocales (Andalucia, Spain), in which positive isolation had been obtained by Brasier et al.

In southeastern France, we isolated $P$. cinnamomi from soil in four out of 16 cork oak sites. At sites 6 and 10, the high fre- quency of pathogen detection in soil samples (2/4 and 3/4) and of cankered trees, the infection of cork oak seedlings (site 6) and of Erica sp. (site 10) suggests that $P$. cinnamomi inoculum potential is high. At sites 12 and $15, P$. cinnamomi was detected, respectively, in one and three out of four soil samples, but no cankers were observed. At sites 2 and $3, P$. cinnamomi was isolated from stem cankers but soil samples had not been taken at the bases of these infected trees. The low or null $P$. cinnamomi detection level might be explained by a lack of effectiveness of isolation methods, the pattern of distribution of the pathogen, the sampling level or the soil inoculum level. However, the use of chestnut stem and of oak leaf as baits improved the detection compared to the one obtained with the direct soil plating method which, in a previous study enabled the quantification of $P$. cinnamomi propagules in $63 \%$ of soil samples in a highly infected red oak site [7]. Effectiveness of isolation methods thus might not be the major cause of the low percentage of positive soil isolation. With only four trees per site and $10 \mathrm{~g}$ of soil per sample, the probability of catching P. cinnamomi is low, especially if its distribution in soil is aggregated and not uniform, as it was proved by Desprez-Loustau and Dupuis [7] and as it is observed with several Phytophthora diseases. This probability also decreases with $P$. cinnamomi population level in soil. This latter depends on the moisture, temperature and composition of soil and on the canopy cover and understorey [21]. At Le Luc and Perpignan, in April and May, rainfall greater than or equal to the normal might have favoured the pathogen_multiplication. But for both years, in June, when we performed our survey, drought ( $2 \mathrm{~mm}$ in 1995 and 14 $\mathrm{mm}$ in 1996) might have restricted $P$. cinnamomi multiplication which occurs during warm and moist periods [21]. In November 1995, soil temperature might have been a limiting factor for $P$. cinnamomi multiplication (average air temperature was $12.5{ }^{\circ} \mathrm{C}$ ). Comparatively, climatic conditions were 
most favourable for $P$. cinnamomi multiplication in the Basque country (southwestern France) where its isolation from soil was more successful [7]. Thus, it is highly likely that a more extensive sampling strategy including different periods would have lead to higher isolation rates. However the aim of our study was not to describe precisely $P$. cinnamomi extension area in southeastern France, but to provide evidence of its presence in this part of the country for which no report existed before.

In Var and in Pyrénées Orientales, presence of $P$. cinnamomi, at the site and tree level, could not be associated with the intensity of dieback symtoms in cork oaks or with soil moisture. The most favourable sites for $P$. cinnamomi spread are reported to be depressions, gully heads and valley bottoms with high soil moisture [21]. However, except at site 21 , we did not find the pathogen at such sites. Three of the stands where it was detected were located on hillsides and two in plains. Similarly, in southwestern France, frequency of trunk cortical cankers caused by $P$. cinnamomi on red oak was higher on hillsides and tops of hills than at valley bottoms [12].

Positive isolations from soil were obtained from sites where human activities (sylvicultural practices, cattle rearing, fertilization and ploughing, etc.) were frequent, and may be linked to the spread of the pathogen in these forest sites and may explain why we found $P$. cinnamomi more often in cork oak sites than in holm oak sites, which were, for the most part, natural and undisturbed forest stands, in which human activities were less frequent. In Australia, $P$. cinnamomi distribution is largely influenced by intensity of human activities, which are responsible for both long and short distance dissemination of the pathogen [21]. In Iberia, oak decline is associated with soil disturbances such as ploughing, animal trampling or road making [4]. P. cinnamomi can also be disseminated by plants. Infected seedlings of cork oaks coming from commercial nurseries have already been observed (unpublished results). Three of the infected sites we studied were plantations.

Pathogenicity of $P$. cinnamomi isolates towards cork and holm oaks was confirmed by the controlled inoculations. Seedlings and 1-year-old plants of $Q$. ilex proved to be more susceptible than $Q$. suber to most of the isolates tested, as well as 1-year-old plants. On the basis of the soil infestation test which more closely mimics the natural process of root infection, holm oaks proved to be as susceptible as chestnuts and more susceptible than cork and red oaks in terms of mortality and percentage of infected taproot. In chestnut and holm oaks, root infection resulted in the decrease in predawn water potential and in mortalities. In red and cork oaks, the assessed root loss was greater than $50 \%$. Still, 7 weeks after inoculation, the root system destruction did not result in a decreasing water potential.

A higher susceptibility of holm oak compared to cork oak was also reported by Tuset et al. [22] after controlled inoculations. From our experimental results, holm oak is expected to be more prone to dieback by $P$. cinnamomi than cork and red oak. We indeed observed one infected holm oak exhibiting a severe yellowing and microphylly. But this tree was located in a swampy part of the site and subjected to periodic floodings, which might favour the inoculum build-up. Description of other infected holm oak sites and impact of $P$. cinnamomi infections on stressed trees are necessary to assess the impact of this pathogen on holm oak. Yet a threat of higher damage in this species has to be considered.

In Pyrénées Orientales, severe decline was observed at the infected cork oak sites. However, this oak decline, as the one observed in Iberian peninsula, may reflect the past climatic events, as has been proposed by different authors $[3,23]$. Indeed the drought which occurred in southwestern Spain from 1980 to 1994 , is one of the most severe in the century [1]. In our experiments and from our field observations in 
Var (sites 2, 3, 6 and 10), cork oak seems to behave as red oak in which cortical trunk cankers caused by $P$. cinnamomi result from infections that develop in the root system without inducing any dieback symptom or any detrimental effect on tree growth [20]. Although under our experimental conditions cork oak seedlings tolerated root loss due to $P$. cinnamomi, it remains to be investigated how infected trees can tolerate decrease in water absorption capacity if they are subjected to other stresses affecting water relations. These stresses may have several different origins: floodings occurring after droughts, cork removal, fires, insects, other pathogens, etc. Studies focusing on interactions between $P$. cinnamomi infections and stresses are required for the understanding of Mediterranean oak decline and for the choice of control methods since the environmental conditions may lead to different outcomes of tree infection by $P$. cinnamomi, as hypothesised by Brasier [3].

\section{ACKNOWLEDGEMENTS}

The authors acknowledge the assistance of $\mathbf{J}$. Mirault, J. Regad, F. Maugard, F. Joliclair and A. Priol for providing stands for the survey, $X$. Capdevielle for taking care of plants, A. Baudry for his help in Phytophthora sp. identification, L. Niquet for her assistance and E. Hansen for helpful comments on the draft.

This study was performed in the frame of the European AIR program 'PHYODE', 3-CT941962.

\section{REFERENCES}

[1] Almarzar C., Balairon L., La sequia en Espana, El Boletin, Ministerio de agricultura, pesca y alimentacion 26 (1995) 49-57.

[2] Anonymous, Le dépérissement du chêne liège, Bulletin de la Documentation forĉt méditcriranćcnnc et incendies 22 (1991) 1-3.

[3] Brasier C., Phytophthora cinammomi and oak decline in southern Europe. Environmental constraints including climate change, Ann. Sci. For. 53 (1996) $347-358$.
[4] Brasier C.M., Robredo F., Ferraz J.F.P., Evidence for Phytophthora cinnamomi involvement in Iberian oak decline, Plant Pathol. 42 (1993) 140-145.

[5] Cobos J.M., Montoya R., Tuset J.J., New damage to Quercus woodlands in Spain, preliminary evaluation of the possible implication of Phytophthora cinnamomi, Proc. Int. Congress 'Recent advances in studies on oak decline', Dipart. di Patologia Vegetale, Universita degli Studi, Bari, 1992, 163-169 pp.

[6] Delatour C., Les dépérissements de chênes en Europe, Revue Forestière Française 35 (1983) 265-282.

[7] Desprez-Loustau M.L., Dupuis F., Spatial distribution and pathogenicity of Phytophthora cinnamomi isolates originating from soil of an infested red oak stand, in: Perrin, Sutherland (Eds.), Diseases and Insects in Forest Nurseries, Les colloques no. 68, Inra, 1994, pp. 79-91.

[8] Globa-Mikhajlenko D.A., A biological method of control of the ink disease of cork oak (in Russian), Zashch. Rast. Moscow 5 (1960) 35.

[9] Grente J., La maladie de l'encre du châtaignier, Ann. Epiphyt. 12 (1961) 5-59.

[10] Jung T., Blaschke H., Neumann P., Isolation, identification and pathogenicity of Phytophthora species from declining oak stands, Eur. J. For. Path. 26 (1996) 273-280.

[11] Landmann G., Becker M., Delatour C., Dreyer E., Dupouey J.L., Oak dieback in France: historical and recent records, possible causes, current investigations, Rundgespräche der Kommission für Ökologie, Bd. 5 (1993) 97-114.

[12] Lévy A., L'encre du chêne rouge d'Amérique: répartition en France, facteurs stationnels dans le piémont des Pyrénées Occidentales, Cahiers du DSF 1 (1995) $1-41$.

[13] Marçais B., Dupuis F., Desprez-Loustau M.L., Susceptibility of Quercus rubra root system to Phytophthora cinnamomi; comparison with chestnut and other oak species, Eur. J. For. Path. 26 (3) (1996) 133-143.

[14] Mircetich S.M., Campbell R.N., Matheron M.E., Phytophthora trunk canker of coast live oak and cork oak trees in California, Plant Disease Reporter 612 (1977) 66-70.

| $15 \mid$ Moreau C., Moreau M., Étude mycologique de la maladic de l'encre du chêne, Rev. Pathol. Veg. 31 (1952) 201-231.

[16] Ragazzi A., Dellavale Fedi I., Mesturini L., The oak decline: a new problem in Italy, Eur. J. For. Path. 19 (1989) 105-110.

[17] Ragarıi A., Vagniluea S., Moricca S., European expansion of oak decline: involved microorganisms and methodological approaches, Phytopath. Medit. 34 (1995) 207-226.

[18] Ribeiro O.K., A Sourcebook on the Genus Phytophthora, J. Cramer, Lehre; Germany, 1978, 420 p.

[19] Robin C.. La maladie de l'encre du chêne rouge (Quercus rubra L) causéc par Phythophthora cinnamomi Rands: Perspectives pour l'amélioration géné- 
tique de la résistance, thèse de l'Université de Bordeaux II, 1991, 140 pp.

[20] Robin C., Desprez-Loustau M.L., Delatour C. Spatial and temporal enlargement of cankers of Phytophthora cinnamomi in red oak, Can. J. For. Res. 22 (3) (1992) 362-366.

[21] Shearer B.L., Tippett J.T., Jarrah dieback: the dynamics and management of Phytophthora cimamomi in the Jarrah (Eucalyptus marginata) forest of Southwestern Australia, CALM, Res. Bull. 3 (1989) 75 pp.

|22| Tuset J.J., Hinarejos J.L., Mira J.L., Cobos J.M., Implication of Phytophthora cimlamomi Rands en la enfermedad de la seca de encinas y alcornoques, Bol. San. Veg. Plagas 22 (1996) 491-499.
[23] Varela M.C.. Erikson G., Multipurpose gene conservation in Quercus suber-a Portuguese example, Silv. Genet. 44 (1995) 28-37.

[24] Vegh I., Bourgeois M., Données préliminaires sur l'étiologie du dépérissement des conifêres d'ornement dans les pépinières françaises; rôle de Phythophthora cinnamomi Rands, Pepinier. Hortic. Maraich. 153 (1975) 39-49.

125| Weste G., Marks G.C., The biology of Phytophthora cinnamomi in Australian forests, Annu. Rev. Phytopathol. 25 (1987) 207-229.

[26] Zentmyer G.A., Phytophthora cinnamomi and the diseases it causes, Monograph no. 10. American Phytopathological Society, St Paul, Minnesota, USA. 1980. 